\title{
A REALISTIC APPROACH TO LABOR LEGISLATION*
}

\author{
WAYNE MORSE $\dagger$
}

$\mathrm{T}$ HE American people are expecting entirely too much of labor legislation as a panacea for industrial ills. I am afraid that too many, both in and out of Congress, have misled themselves into thinking that a maximum of industrial freedom in this country can be attained by putting American labor into a legislative strait-jacket. They have not stopped, I fear, to study the history either of the American labor movement or of the experiences which have resulted in the passage from time to time of restrictive, punitive labor legislation in some of our states.

Legislation of a punitive, restrictive, prohibitive type in the field of labor relations has invariably met with great resistance. It always provides the agitator and radical labor leader with plausible propaganda against employers. It permits of the emotion-arousing type of argument that "industry and your employers control the state legislatures, the Congress, and the courts, and through their political power even use the law to deny you economic justice." Unsound as such arguments are, the fact is that, when confronted with an unjust law, it is only natural that working people resent its passage and find it easy to attribute bad motives to both employers and public officials.

I think it is a fair statement to say that unfair restrictive labor legislation will always cause more labor trouble than it will ever be successful in preventing. What happens after the passage of such legislation is that, for a time, usually only for a brief time, labor suffers a setback; and then it begins to dig in along a united front, inspired by the single objective of freeing itself from the shackles of such unfair legislation. It is an old pattern that has been repeated over and over again throughout the history of the American labor movement; and it will always be repeated, in my judgment, so long as we attempt to do by legislation what American employers and workers should do by good faith, free, collective bargaining.

It is bad legislative policy and it is not in the interest of government to pass legislation which is going to be so opposed by such a large number of people that its enforcement becomes next to impossible. It is, of course,

* Extracted by Senator Morse for the Review from his remarks before the Senate, March Io, 1947 .

$\dagger$ United States Senator from Oregon. 
easy to say that if labor wants to make a test between itself and the government, Congress should pass legislation forcing that test; but there is little realism in such an attitude, because when any law is unacceptable to such a large number of people that it cannot be enforced successfully it becomes a dead letter. In a democratic society we cannot afford to place upon the administration of justice a greater strain than it can well bear. We do not strengthen government by law by adopting legislation which is certain to break down in its enforcement.

It is important to direct attention to the main objective of the American free labor movement - the securing for the workers a greater share of the wealth produced by their labors. This objective does not at all frighten me since I recognize it as essential to the preservation of our capitalistic economy. And I want to see that economy preserved because political democracy cannot be separated from economic democracy. It is a mistake for people to brand as socialistic the objective of organized labor to secure for itself a more equitable share of the product of its labor. In fact, I think that if progress toward that objective will only keep pace with increased production of national wealth we shall have a complete rebuttal to those agitators and leftists who in some small cells of American labor are trying to convince workers that our capitalistic system denies them their economic rights.

I am not one who believes that any totalitarian ideology is a serious threat to a continuation of our American economic system based upon private property and the right to make fair profits from the investments of capital and wealth-producing enterprises. I do think that if we are to keep our system secure and economically healthy we must avoid depressions and the cycle of boom and bust. We cannot afford the economic loss which flows from such breakdowns in our economic machinery. We cannot justify the human suffering resulting from the unemployment, the hunger, and the fears of economic insecurity which result from such breakdowns. They are unnecessary if American labor, industry, agriculture, and all other segments of our economic population will recognize that it is not regimentation to develop co-operative planning between and among a friendly government, labor, industry, farmers, and all the rest of us to the end of maintaining full employment, high production, and a fair distribution of profits. There is no other answer if our American system is to accomplish the great economic objectives of which it is capable.

I do not agree with those who argue that depressions are a part of the price of freedom, or that economic insecurity for millions of our fellow American citizens is unavoidable under a free-enterprise system. If that 
were true, then the system would be for the enterprisers, with little freedom for the rest of us. Those who hold to the views that depressions, unemployment, and economic insecurity are unavoidable social and economic results of our capitalistic system perform a great disservice to that system. They should recognize that depressions produce tremendous discontent, and greatly increase the number of people who, in the midst of their troubles, fears, and panic, reach the conclusion that they have little if anything to lose from an economic change. There were signs of that during the early thirties, when segments of our population showed some manifestations of direct action. It is out of such social phenomena that great political and economic changes can take place in a country.

The major objective of the American labor movement has served over our history as a great stabilizer of our capitalistic system. As our workers have joined themselves together in effective labor-union organizations for the advancement of their economic welfare they have succeeded over the years in raising the level of real wages to a point far above that of any other workers in the world.

The standard of living of all Americans has benefited greatly from the economic campaign which organized labor has waged over the years for better wages, hours, and working conditions. I know of no group in our country which has benefited more from organized labor's endeavors to raise the standard of living of the workers of the country than the American employers, businessmen, and industrialists themselves.

Our system of competitive enterprise can sustain itself only on the purchasing power of the consumers of the country. Lower that purchasing power and the charts and graphs of our economic statisticians begin to show immediately serious distortions in the movement of economic goods through the channels of trade. Paradoxical as it may seem the fact is that our profit system depends upon distributing profits into the pockets of the consumers of America. This includes for the most part the workers, the farmers, and the millions who make up our so-called white-collar class. The base of that distribution of profits must be a wide one because the expansion and ever greater productivity of our private-enterprise system depends upon the purchasing power of the American consumer. Profits cannot be made out of a contracting and declining production. It is increased production and expansion through new industry which develops the economic power of our system and makes possible a higher purchasing power through a greater distribution of profits among our consumers.

In the midst of the present tremendous propaganda drive for punitive 
labor legislation, it is easy for the American people to forget what has happened in the past-and what is bound to happen again in the future if certain types of employers are freed from the limitations of the Wagner Act. In fact, no one can study the American industrial scene without recognizing that in the competitive struggle for profits it is easy to treat human beings as commodities to be bought and sold on the labor market on the basis of supply and demand unless the government is ever vigilant -through such legislation as the Wagner Act, the Fair Labor Standards Act, safety legislation, and all the rest of our much needed labor legislation-to protect the freedom of free workers.

One cannot sit in the hearings of the Senate Committee on Labor and Public Welfare and listen to the various types of employer witnesses who have come before us without frequently being shocked and disappointed on discovering that there are still many powerful employers in America who believe that the free-enterprise system is synonymous with a benevolent paternalism under which they shall enjoy the license of parceling out the benevolence as best suits their selfish interests. I think it is important that voices be heard in America these days pointing out that there are still many employers who have not learned-or who are not willing to admit - that collective bargaining through the elected representatives of the workers is here to stay; and that if they continue in their drive to tear down the benefits achieved by organized labor they will tear down also the liberties of organized industry and seriously cripple the economy of the nation.

If we abolish the Wagner Act, within less than six months American industrial life would in large part return to the unfair labor practices that existed prior to its passage. There is too much evidence of an attitude of union busting and anti-labor sentiment in some of the employer witnesses appearing before the Labor Committee. The extremists among American employers are still sufficiently large in number so that the repeal of the Wagner Act will result in another era of labor exploitation that ultimately would lead to tremendous violence and chaos.

We cannot preserve a political democracy alongside an employer-industrial dictatorship. The United States of this decade cannot survive as a political Dr. Jekyll and an economic Mr. Hyde-as a political democracy and a laissez faire economy. Either we are going to march forward ás a political and an economic democracy, with a free and co-operative government maintaining only such minimum standards of control as are necessary to protect the economic weak from exploitation by the economic 
strong, and yet allow free play for American initiative and ingenuity, or we are going to destroy our rights as a democratic people by adopting some form of economic totalitarianism or industrial anarchy.

If we should permit the strangle hold of monopolist practices of big business to continue its death grip upon the throat of private enterprise, we shall develop a form of economic totalitarianism by a relatively few business tyrants in America.

If, coupled with that serious and ominous threat to our free-enterprise system, we should repeal or emasculate such pieces of social and labor legislation as the Wagner Act, the Social Security Act, and the Fair Labor Standards Act, we shall succeed only in strengthening the forces of those whose practices and policies-if permitted to go unchecked-would lead to economic totalitarianism in America.

Labor, however, has some grave responsibilities and obligations in connection with the operation of our capitalistic system. It has no more right to seek to profiteer at the expense of a stable economy than have the employers and the industrialists. Labor can destroy its own house if it listens to those radicals in its midst who would misrepresent the extent of industrial profits.

The need for applying a fair share of profits to new capital investments is too frequently ignored by some labor leaders when making their demands upon employers. Such capital investments are essential if we are to meet the needs at all times of full employment and increased production of national wealth out of which new tax dollars can flow. Labor must recognize that if we are to protect the value of the dollar we must increase the production of new wealth out of which we can get the taxes necessary to reduce our national debt which in its present amount threatens the standard of living of all of us-including labor.

It is a common shortcoming of humans to seek to advance their own selfish interests by taking advantage of the other fellow's interests. Labor is no exception to that rule of human conduct. It is no more entitled to exemptions from legal checks upon its excesses than are employers, businessmen, and corporations. It too must be required to advance its legitimate interests within a framework of law approved by the people as a whole. It does not follow that reasonable legal restrictions which protect the individual worker and the public from union excesses deny any fundamental freedoms to organized labor.

Certainly, the principle of reasonable regulation and control, necessary to check excesses, does not in the abstract deny labor any basic rights. It 
is the application of the abstract principle in the form of specific legislation which presents the real test. The main point, however, is that labor, too, in a government of law rather than men, must recognize that its rights are relative and not absolute, in that they must be exercised in a manner that will promote the common good and not just the selfish good of labor alone. It is to be regretted that much of the need for corrective legislation grows out of the failure on the part of labor to do voluntarily some of the things which now I am satisfied it must be required to do by law.

To meet this need for corrective legislation, I have presented to the Senate a bill ${ }^{\mathrm{x}}$ proposing certain amendments to the National Labor Relations Act. These amendments fall into four general categories:

First. Several new unfair labor practices with regard to labor organizations and their agents are defined and certain deficiencies in the present unfair labor practice sections are corrected;

Second. The constitutional right to free speech is guaranteed to employers and all other persons affected by the act;

Third. The board, as the expert agency of the government dealing with labor relations, is permitted to seek injunctive relief in the circuit courts to restrain unfair labor practices of both employers and employees when the board is persuaded that the situation demands speedy relief;

Fourth. In view of the increased amount of work placed upon the board its size is increased from three to seven members.

New unfair labor practices. Just as the Wagner Act now makes it unfair for an employer to interfere with or restrain his employees in the exercise of their right to select their collective-bargaining representative, so I propose that it be an unfair labor practice for labor organizations, or their agents, to interfere with an employer in the selection of his bargaining representative.

I have also attempted to define as unfair labor practices strikes and secondary boycotts directed at certain objectives. For example, it would be an unfair labor practice to strike or boycott in furtherance of a jurisdictional dispute regarding the performance of particular work tasks by members of one union or another. These jurisdictional disputes are generally unjustifiable and need to be corrected. Another objective for which it would be illegal to engage in a strike or boycott would be to compel any employer to disregard a certification issued by the board. At present an employer who is under duty to bargain with one union by reason of a board election and certification can obtain no relief from the board or the

rS. 858, 8oth Cong. Ist Sess. (I947). 
courts if the union which lost the election chooses to strike or boycott in an effort to have the employer disregard the obligation placed upon him by reason of the board certification. Another objective which it seems to me is not defensible is that involved in a secondary boycott designed to force an employer to recognize a union. With the democratic election machinery of the Wagner Act available, and with the provisions according federal protection to employees in their efforts to organize, it is no longer legitimate for labor to engage in this type of conduct.

The third type of unfair labor practice covered by this bill is that arising out of expulsion of employees from membership in a union which has a closed-shop contract with an employer, when the reason for the expulsion is that the employee has exercised his democratic right to change bargaining representatives. The board can now remedy such conduct only by the indirect method of issuing an order against the employer who, in response to a union demand, discharges the employee after he has been expelled from the union. The board can act in this indirect manner only when the facts show that the employer had knowledge that the contracting union expelled the employee for exercising his right under the act. To the extent that the union is solely responsible for the discharge, it should be answerable. If both the employer and the union are responsible, both should be answerable. In the interest of maintaining contractual and in dustrial stability, however, it is desirable that employees be free to engage in activities designed to change representation only at appropriate times. I have, therefore, protected such activity only when it occurs "at a time when a question concerning representation may appropriately be raised." The purpose here is to write into law the principle now followed by the board of allowing election petitions to be filed near the end of the contract period.

Much has been said concerning the obligation of unions to bargain collectively. While it seems to me that unions would seldom refuse to engage in collective bargaining since that is one of the primary, if not the primary, reason for their existence, I can see no valid objection to imposing that duty on them by law. Therefore, it is proposed that it be an unfair labor practice for a union to refuse to bargain collectively after it has been certified by the board as the exclusive representative.

Finally, I propose that it be made an unfair labor practice for a union to violate the terms of a collective-bargaining agreement to submit a labor dispute to arbitration. In this connection I am also proposing that similar conduct by an employer be made an unfair labor practice. While it is my 
view that unions and employers should settle their contractual disputes by collective bargaining and voluntary arbitration, I recognize the force of the argument that existing law affords only nebulous remedies to employers as well as unions in case the other party has violated the contract. It is expected that under such an amendment the board would devise regulations and pursue a policy which would minimize the number of contract violation cases accepted.

It would be a great mistake for the government to undertake to adjudicate as unfair labor practices all alleged violations of collective-bargaining contracts. Certainly this procedure should not be used until the parties have exhausted the remedies available under their contract or through voluntary arbitration.

Greater fairness in the administration of the Wagner Act will be obtained if an employer is permitted to file a petition with the board and obtain an election. Although the present act does not preclude the board from accepting an employer petition, by its rules and regulations it allows an employer to file only when conflicting demands for recognition have been presented to him by two or more labor organizations. It is proposed, therefore, to permit any party in interest to request an election. It is recognized, however, that such a right may be subject to abuse in that employers may seek an election at the earliest possible moment in an organizational campaign and thereby obtain a vote rejecting the union before it has had a reasonable opportunity to organize. The employer's right to file a petition would, therefore, be limited to those situations in which the union has made a claim to be recognized as the exclusive bargaining representative, or where, near the end of a contract, bona fide doubt exists that the union which has the contract continues to be the exclusive representative.

Employer free speech. It is, of course, self-evident that neither the board nor the courts can impair the right of free speech guaranteed in the Constitution. It is my impression that those who propose legislation designed to enlarge the employer's right to express his views to his employees are not so much interested in vindicating their constitutional rights as they are in obtaining statutory immunity for acts and conduct which in fact interfere with and coerce employees. If for no other purpose than to correct a widespread misconception and at the same time to impress upon the board its obligations under the Constitution, a new section is proposed specifically guaranteeing that all persons-employers as well as unionsare to be protected in their right of free speech. Further, the board would 
be prohibited from finding any oral or written statement to be an unfair labor practice if the statement by itself or in its context contains no threat of force or economic reprisals.

Injunctive relief. I have been considerably troubled by various proposals which have been made to obtain speedy relief from unfair labor practices, particularly proposals dealing with injunctive relief against conduct by unions and employees. Some of these proposals would revive the days of the midnight injunction, treble-damage actions against unions and employees, and severe criminal penalties. On the other hand, I must admit there is merit in the argument that in many instances of serious and widespread labor disputes the government is in large part impotent to correct the conditions which have led to serious interruption of commerce.

To my mind legislation is necessary to permit the government, through the NLRB, to obtain speedy judicial relief when labor disputes which involve unfair labor practices threaten seriously to impair vital sections of the national economy. I have several proposals designed to strengthen the government in these situations.

First, in the case of jurisdictional disputes involving who shall perform particular tasks, the board would be empowered to appoint an arbitrator to settle the matter unless within ten days the parties satisfy the board that the dispute has been adjusted or that agreement has been reached for the voluntary adjustment of the dispute. After this arbitrator has ren-. dered his award, which is to be filed with the board, if the parties comply, the unfair labor practice charge would be dismissed. One of the reasons for the appointment of an arbitrator is that in jurisdictional disputes time is of the essence and regular board procedure for hearing and judicial enforcement would not remedy the evil sought to be corrected.

Another change in the remedies available to the board would permit the board to obtain a temporary injunction or restraining order from the courts of appeal after the board has issued a complaint but before it has held a hearing and issued an order. Since it is the duty of the board to prevent unfair labor practices, it should have adequate authority to discharge that duty expeditiously.

This proposal would in no way impair the legitimate rights of labor under the Norris-LaGuardia and Clayton acts, since it is not proposed that employers be allowed to obtain injunctions against labor or that unions and their members be subjected to the drastic civil and criminal penalties that could be applied in days gone by. Under this proposal it would be necessary, of course, for the NLRB to exercise an informed dis- 
cretion in administering the law to the end that labor and industry would be encouraged to adjust their differences by the peaceful methods of collective bargaining.

Probably one of the greatest benefits that will come from the adoption of such amendments to the National Labor Relations Act as I have proposed will be action on the part of unions themselves to see to it that it will rarely become necessary to resort to the machinery established. I believe that declaring certain actions to be unfair labor practices will be preventive of some of the abuses we seek to cure because the unions themselves will establish within their own organizations machinery for the settling of such disputes short of economic action. 